\title{
PRANATA PERKAWINAN DALAM AGAMA ISLAM DAN KRISTEN; SEBUAH STUDI KOMPARATIF INTEGRATIF
}

\author{
Moch. Nurcholis \\ Institut Agama Islam Bani Fattah Jombang, Indonesia \\ E-mail: cholis1986@gmail.com
}

\begin{abstract}
s
Not been much found a study evaluating the comparativeintegrative among one religion to another religion related regulation of marriage are sourced directly from the scriptures respective religion, in particular Islam and Christianity. This is to give a balanced understanding and response to gender issues, social inequality relation of husband and wife is exhaled by Western scholars-Christians who are quite a lot of cornering the teachings of Islam. Starting from this idea authors conducted research using descriptive-analytic method to then compare giving rise similarities and differences to material for further research. The study concluded that marriage in Islam can be said to have a double dimension; vertical and horizontal dimensions, whereas the more dominant Christian vertical dimension though there is also a horizontal dimension, as well as striking differences more visible on the issue of legal origin of marriage, polygamy, the permanence of marriage and the problem of intermarriage.
\end{abstract}

Keywords: Institution of Marriage, Islam, Christianity 


\section{Pendahuluan}

Perkawinan merupakan pranata sosial-keagamaan yang mendapatkan perhatian oleh seluruh agama, baik dengan dukungan secara penuh maupun disertai beberapa catatan. Dalam konteks keIndonesiaan, peraturan tentang perkawinan tertuang dalam Undang-undang Nomor 1 Tahun 1974 tentang Perkawinan. Dalam sejarah penyusunannya ketika masih dalam taraf pembahasan dan menjelang pengesahan RUU sempat terjadi penolakan melalui demonstrasi besar-besaran oleh umat Islam, oleh karena muatannya dianggap sangat liberal dengan indikasi adanya pengakuan tentang kawin campur. Namun pada akhirnya RUU tersebut berhasil disahkan dengan perubahan-perubahan yang dituntut oleh umat Islam. Permasalahan perkawinan di Indonesia memang tergolong permasalahan yang cukup sensitif sebab di dalamnya terkandung ajaran keagamaan yang ada di Negara Indonesia. Agama Islam, Kristen, Katolik, Hindu, Budha dan lain sebagainya seluruhnya mempunyai seperangkat aturan tentang perkawinan. Oleh karena sensitivitas itulah, diperlukan adanya kajian tentang perbandingan pranata perkawinan antar agama agar mencapai kesepahaman bersama sehingga terhindar dari konflik. Dalam tulisan ini hanya membahas perkawinan dalam agama Islam, sebagai agama mayoritas, dan Kristen sebagai agama terbesar kedua dengan judul Studi Komparatif Pranata Perkawinan Islam Dan Kristen. Masalah yang akan diteliti menyangkut atas 2 (dua) hal; Pertama, bagaimana ketentuan pranata perkawinan dalam agama Islam dan Kristen? Kedua, Bagaimana komparasi pranata perkawinan dalam agama Islam dan Kristen? Metode yang dipakai dalam penelitian ini menggunakan deskriptif-analisis. Data diperoleh melalui pelacakan dan telaah terhadap kitab suci masing-masing agama, serta melalui wawancara dengan tokoh agama terkait. Data yang telah terkumpul kemudian dianilisi menggunakan metode content analisis (analisis isi) menyangkut ketentuan pranata perkawinan dari kitab Suci Agama Islam dan Kitab Suci Agama Kristen. Hasil analisis kemudian akan dicoba bandingkan diantara keduanya, sehingga memunculkan persamaan dan perbedaan yang dapat bermanfaat untuk bahan penelitian selanjutnya. 


\section{Perkawinan dalam Agama Islam}

a) Pengertian Perkawinan

Ulama hanafiyah berpendapat bahwa kata kawin itu mengandung arti secara haqîah untuk hubungan kelamin, dan berarti akad dalam arti majâz. ${ }^{1}$ Sedangkan secara istilah adalah:

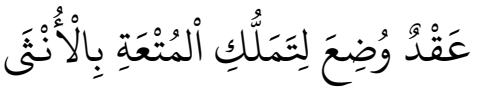

Artinya: "Akad yang ditentukan untuk memberi bak kepada seorang laki-laki menikmati kesenangan dengan seorang perempuan." 2

Berbalik dengan pengertiannya Ulama hanafiyah di atas, ulama Shafi'iyah berpendapat bahwa perkawinan ialah:

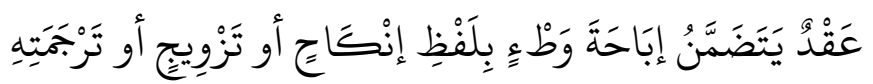

Artinya: "Suatu kontrak untuk menghalalkan bubungan kelamin antara kedua belah pibak dengan menggunakan lafal inkâh atau tazwîj atau terjemahannya." 3

Pengertian-pengertian yang diberikan ulama di atas nampaknya hanya mengemukakan hakikat utama dari suatu perkawinan. Definisi lebih lengkap diungkapkan oleh Ahmad Ghandûr dalam bukunya alA Aswâl al-Shakhsiyyah fi al-Tashrì al-Islâmiy sebagaimana dicuplik oleh Amir Syarifuddin, dengan mengatakan:

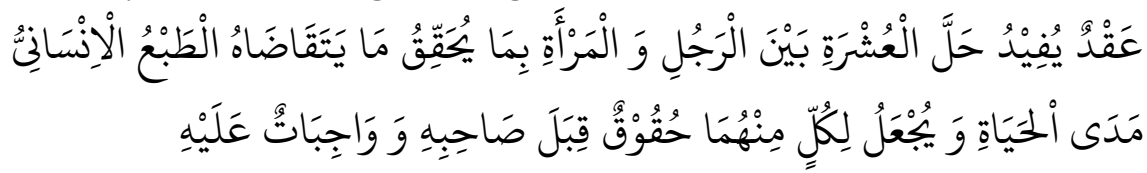

Atinya: "Akad yang menimbulkan kebolehan bergaul antara laki-laki dan perempuan dalam tuntutan naluri kemanusiaan dalam kehidupan, dan menjadikan untuk kedua belah pibak secara timbal balik hakbak dan kewajiban-kewajiban." ${ }^{4}$

Ujung dari pengertian ketiga yang merupakan tambahan dari dua pengertian sebelumnya mengandung maksud bahwa salah satu akibat

\footnotetext{
${ }^{1}$ Kamâl al-Dîn Muhammad bin 'Abd al-Wahị̂d al-Sîwâsî, Sharh Faṭh al-Qadîr, (Bairut: Dâr al-Fikr, t.th.), 185.

2 Al-Sîwâsî, Sharh....., 186.

3 Zakariyyâ al-Aṇ̂âî, Athnâ al-Mạtâlib fì Sharh Raudh al-Tâlib, (Bairut: Dâr al-Kutub al'Alamiyyah, 2000), 98.

${ }^{4}$ Amir Syarifuddin, Hukum Perkawinan Islam di Indonesia, (Jakarta: Prenada Media, 2007), 39.
} 
dari adanya akad perkawinan itu adalah timbulnya hak dan kewajiban timbal balik antara suami istri. ${ }^{5}$

b) Asas Perkawinan

Dalam Islam terdapat 6 (enam) asas prinsipil tentang perkawinan, yakni:

1) Tujuan perkawinan adalah membentuk keluarga yang bahagia dan kekal; ${ }^{6}$ Hal ini sesuai dengan firman Allah:

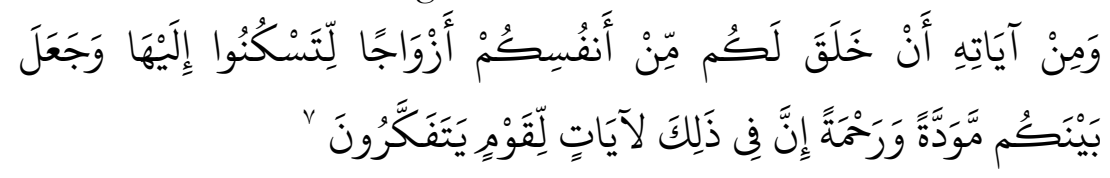

Artinya: "Dan diantara tanda-tanda kebesaran-Nya ialah bahwa Ia telah menciptakan untuk kamu jodoh-jodahmu dari kalanganmu sendiri, agar kamu merasakan sakinah (ketentraman) dalam jodoh-jodoh itu, serta dibuat oleh-Nya mawaddah (katresnan) dan rahmah (cinta kasih) antara sesamamu. Sesunggubnya dalam hal itu ada tanda-tanda (kebesaran Tuhan) bagi Komunitas yang berpikir." 8

2) Suatu perkawinan sah apabila dilakukan menurut hukum masingmasing agamanya dan kepercayaannya;

3) Menganut asas monoandri tertutu, dam monogami terbuka. Dalam hal monogami terbuka berlaku hanya apabila dikehendaki oleh yang bersangkutan, karena hukum dan agama dari yang bersangkutan mengizinkan seorang suami dapat beristeri lebih dari seorang; ${ }^{10}$ Sesuai dengan firman Allah:

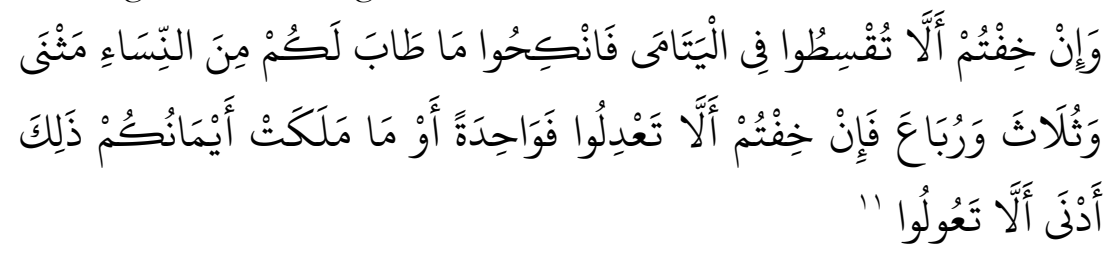

\footnotetext{
5 Amir Syarifuddin, Hukum...., 39.

6 'Abdul Kadir Muhammad, Hukum Perdata Indonesia, (Bandung: PT. Citra Aditya Bakti, 2000), 70.

7 Al-Qur'an, 30: 21.

${ }^{8}$ Departemen Agama RI, Al-Qur'an dan Terjemahannya, (Bandung: Menara Kudus, 2006), 406.

9 'Abdul Kadir Muhammad, Hukum Perdata Indonesia....., 70.

10 'Abdul Kadir Muhammad, Hukum Perdata Indonesia....., 70.

11 Al-Qur'an, 4: 3.
} 
Artinya: "Dan jika kamu takut tidak akan dapat berlaku adil terbadap (bak-bak) perempuan yatim (bilamana kamu mengawininya), maka kawinilah wanita-wanita (lain) yang kamu senangi, dua, tiga, atau empat. Kemudian jika kamu takut tidak akan dapat berlaku adil, maka (kawinilah) seorang saja atau budak-budak. yang kamu miliki. Yang demikian itu adalab lebib dekat kepada tidak berbuat aniaya." 12

4) Calon suami istri harus telah masak jiwa raganya untuk dapat melangsungkan perkawinan, agar dapat mewujudkan tujuan perkawinan secara baik tanpa berpikir pada perceraian dan mendapat keturunan yang baik dan sehat. ${ }^{13}$ Sesuai dengan alQur'an, 30: 21, sebagaimana yang telah tercantum di atas;

5) Karena tujuan perkawinan membentuk keluarga yang bahagia, kekal dan sejahtera, maka juga menganut asas untuk mempersulit terjadinya percaraian; ${ }^{14}$ Sesuai dengan sabda Rasulullah SAW, riwayat Ibn 'Umar:

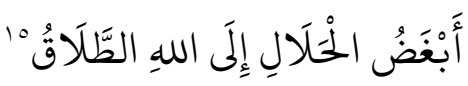

Artinya: "Perbuatan halal yang paling dibenci Allab adalah perceraian."

6) Hak dan kedudukan istri adalah seimbang dengan hak dan kedudukan suami, baik dalam kehidupan rumah tangga maupun dalam pergaulan masyarakat, sehingga dengan demikian segala sesuatu dalam keluarga dapat dirundingkan dan diputuskan bersama oleh suami istri. ${ }^{16}$ Sesuai dengan firman Allah:

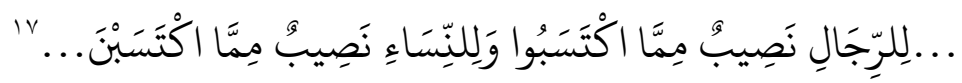

Artinya: “...(karena) bagi orang laki-laki ada kebahagiaan dari pada apa yang mereka usahakan, dan bagi para wanita (pun) ada bagian dari apa yang mereka usahakan..."18

\footnotetext{
12 Departemen Agama RI, al-Qur'an ....., 77.

13 'Abdul Kadir Muhammad, Hukum Perdata Indonesia....., 70.

14 'Abdul Kadir Muhammad, Hukum Perdata Indonesia....., 71.

15 Abû Dâwud Sulaimân bin al-Ash'ab al-Sijistânî, Sunan Abî Dâwud, (Bairut: Dâr alKitâb al-'Arâbî, t.th.), 220.

16 'Abdul Kadir Muhammad, Hukum Perdata Indonesia....., 71.

17 Al-Qur'an, 4: 32.

${ }^{18}$ Departemen Agama RI, Al-Qur'an ....., 83.
} 


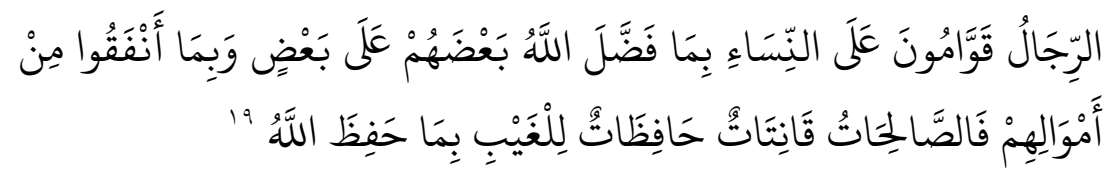

Artinya: "Kaum laki-laki adalah pemimpin bagi kaum wanita, oleh karena Allah telah melebibkan sebagian mereka (laki-laki) atas sebagian yang lain (wanita), dan karena mereka (laki-laki) telah menafkabkan sebagaian dari harta mereka. Sebab itu maka wanita yang saleh, ialah yang taat kepada Allah lagi memelihara diri dibalik pembelakangan suaminya oleh karena Allah telah memelihara (mereka)." 20

c) Rukun dan Syarat Sah Perkawinan

Rukun perkawinan ialah hakikat dari perkawinan itu sendiri, jadi tanpa adanya salah satu rukun, perkawinan tidak mungkin dilaksanakan. ${ }^{21}$ Rukun perkawinan terdiri atas calon suami, calon isteri, wali kawin, dua orang saksi dan ijab dan kabul. ${ }^{22}$ Sayyid Sâbiq dalam kitab Figh Sunnah berkata bahwa syarat sah perkawinan adalah syarat-syarat yang menjadikan penetapan status perkawinan dianggap sah, dengan melihat ketika telah melakukan akad perkawinan yang sesuai dengan syarak. Dan setelah itu diwajibkan bagi suami dan istri untuk melakukan seluruh kewajibannya. ${ }^{23}$

Secara umum dalam kitab-kitab fikih, perkawinan antar dengan pemeluk agama lain tidak diperbolehkan, keculai dalama kasus perkawinan antara seorang laki-laki muslim dan wanita kitabiyah, yang menurut beberapa pendapat adalah yang beragama Yahudi dan Nasrani. ${ }^{24}$ Pemahaman ini didasarkan pada:

${ }_{19}$ Al-Qur'an, 4: 34.

${ }^{20}$ Departemen Agama RI, Al-Qur'an...., 84.

21 Soemiyati, Hukum Perkawinan Islam dan Undang-Undang Perkawinan, (Yogyakarta: Liberty, 1999), 30.

22 Zakariyâ bin Muḥammad bin Ạ̣mad bin Zakariyâ al-Aṇ̂ârî, Fatḥ al-Wabhâb bi Shaṛ Manhâj al-Tullâb, (Bairut: Dâr al-Kutub al-'Tlmiyah, 1418 H), 58.

${ }^{23}$ Sayyid Sâbiq, Fiqh al-Sunnah, (Kairo: Dâr al-Sunnah, 2009), 56.

24 Ahmad Rafiq, Hukum Islam di Indonesia, (Jakarta: PT. Raja Grafindo Persada, 2003), 344. 


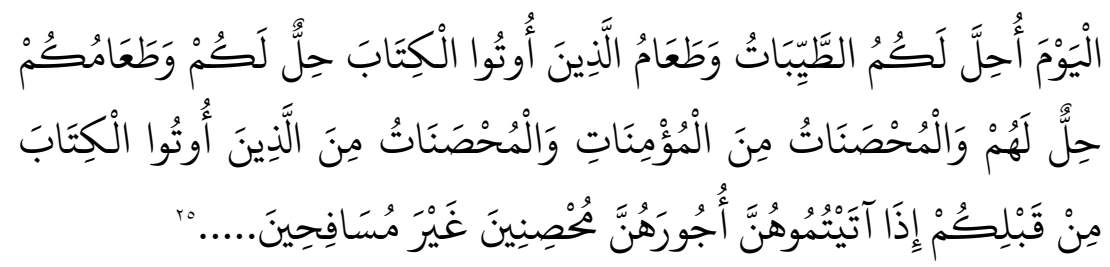

Artinya: "Pada hari ini dihalalkan bagimu yang baik-baik, makanan (sesembelihan) orang-orang yang diberi kitab itu halal bagimu, dan makanan kamu halal (pula) bagi mereka. (Dan dihalalkan mengawini) wanita-wanita yang menjaga kehormatan di antara wanta-wanita yang beriman dan wanita-wanita yang menjaga kehormatan di antara orang-orang yang diberi al-Kitab sebelum kamu bila kamu telah membayar maskawin mereka dengan maksud menikabinya..... ${ }^{, 26}$

Berkaitan dengan ayat di atas al-Nawawî menjelaskan bahwa menurut Imâm al-Syafi'̂̂, kebolehan laki-laki muslim mengawini wanita kitâbiyah tersebut apabila mereka beragama menurut Taurat dan Injil sebelum diturunkannya al-Qur'an. Namun setelah diturunkan al-Qur'an, dan mereka tetap beragama menurut kitab-kitab tersebut, tidak termasuk ahli kitab. ${ }^{27}$

d) Hukum Perkawinan

Para ahli fikih berbeda pendapat tentang adanya hukum dalam perkawinan, apakah wajib atau boleh atau yang lainnya, yang secara terperinci adalah sebagai berikut: ${ }^{28}$

1) Wajib, jika seseorang menyakini bahwa dirinya akan terjerumus dalam perzinaan seandainya tidak melakukan perkawinan. Pendapat wajib ini juga sesuai dengan pendapat Imâm Dâud alZâhirî, yang berpendapat bahwa hukum perkawinan adalah wajib satu kali dalam hidup karena sesuai dengan ayat dan hadis yang menyuruh tentang perkawinan. ${ }^{29}$ Ayat dimaksud adalah:

\footnotetext{
25 Al-Qur'an, 5: 5.

${ }^{26}$ Departemen Agama RI, Al-Qur'an...., 107.

${ }^{27}$ Al-Nawâwî, Al-Tafsîr al-Munîr li Ma'âlim al-Tanzî̀l, (Semarang: Usaha Keluarga, t.th.), 192.

${ }^{28}$ Abû Zakariyyâ Muhyî al-Dîn Yaḥya bin Sharf al-Nawâwî, al-Majmû' Sharh Muhadhdhab (Jeddah: al-Maktab al-Irsyad, t.th.), 202.

${ }^{29}$ Al-Faqîh Abû al-Wâhị̂d Muḥammad bin Aḥmad bin Mụ̣ammmad bin Rushd, Bidâyat al-Mujtabîd, (Jakarta: Pustaka Amani, 2007), 394.
} 


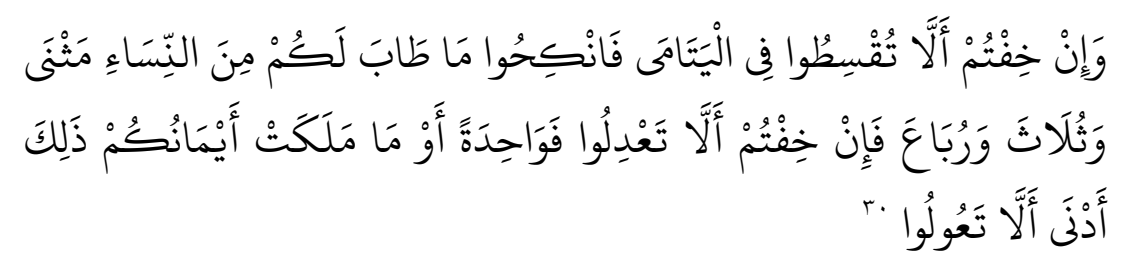

Atinya: "Dan jika kamu takut tidak akan dapat berlaku adil terbadap (bak-hak) perempuan yatim (bilamana kamu mengawininya), maka kawinilah wanita-wanita (lain) yang kamu senangi, dua, tiga, atau empat. Kemudian jika kamu takut tidak akan dapat berlaku adil, maka (kawinilah) seorang saja atau budak-budake yang kamu miliki. Yang demikian itu adalab lebib dekat kepada tidak berbuat aniaya." 31

Sedangakan hadis Nabi berbunyi:

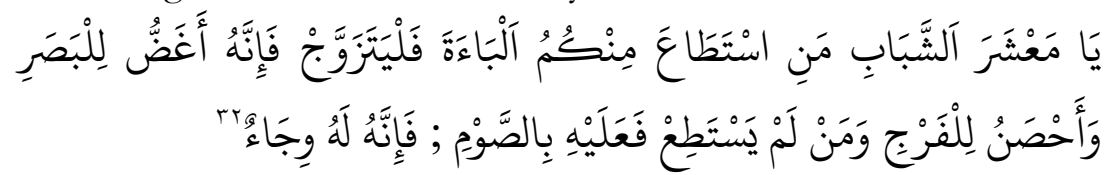

Artinya: "Rasulullah Shallallaabu 'alaibi wa Sallam bersabda pada kami: "Wahai generasi muda, barangsiapa di antara kamu telah mempunyai kemampuan (secara fisik dan harta), hendaknya ia kawin, karena ia dapat menundukean pandangan dan memelihara kemaluan. Barangsiapa belum mampu bendaknya berpuasa, sebab ia dapat meredam (Syahwat)"

Dan juga hadis berbunyi:

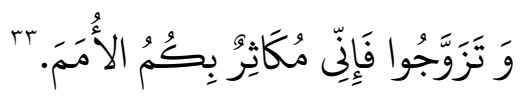

Artinya: "Kawinlah kamu, karena sesunggubnya dengan kawin, saya berlomba-lomba memperbanyak umat dengan umat lain."

2) Haram, jika seorang laki-laki menyakini bahwa akan mendzalimi dan memberikan ke-maz̧ârat-an kepada istrinya. Syekh al-Ușaimin menjelaskan perkawinan yang haram adalah perkawinan yang dilakukan di Dâr al-Harb (Negara yang memusuhi umat Islam), karena dikhawatirkan musuh akan mengalahkan umat Islam dan

\footnotetext{
30 Al-Qur'an, 4: 3.

${ }^{31}$ Departemen Agama RI, Al-Qur'an...., 77.

32 Abû al-Husain Muslim bin al-Hujjâj bin Muslim al-Qushairî al-Naisâbûrî, Sabịh Muslim, (Bairut: Dâr al-Afâq al-Jadîdah, t.th.), 128.

33 Muḥammad bin Yazîd Abû 'Abdillâh al-Qazwinî, Sunan Ibn Mâjạh, (Bairut: Dâr alFikr, t.th.), 592.
} 
anak-anaknya akan dijadikan budak. Tetapi jika dilakukan dalam keadaan darurat, maka dibolehkan;

3) Makruh, jika seorang laki-laki takut dirinya akan menzalimi seorang wanita dan memberikan ke-mazâarat-an kepadanya;

4) Sunnah, jika seorang laki-laki mampu menikah, yakni mampu memberi nafkah istrinya, dan tidak dikhawatirkan terjerumus dalam perzinaan seumpama tidak menikah, dan jika menikah tidak akan menzalimi dan memberikan ke-mazâarat-an kepada istrinya. ${ }^{34}$ Pendapat ini sesuai pendapat Imâm Mâliki. ${ }^{35}$ Berkaitan dengan hukum sunnah ini, Imâm Nawâwî berkata: "Ini adalah mazhab kita (Shâfi'izah) dan mazhab seluruh ulama, bahwa perintah kawin di sini adalah anjuran, bukan kewajiban dan tidak diketahui seseorang mewajibkan kawin kecuali Dâud dan orang-orang yang setuju dengannya dari pengikut Ahl Zâhir (Zâhbiriyah), dan riwayat dari Imâm Aḥmad". 36

5) Boleh, bagi orang yang mempunyai syahwat, tetapi tidak mempunyai harta, atau mempunyai harta tetapi tidak mempunyai syahwat. Pendapat ini adalah pendapat jumhur ulama. ${ }^{37}$

Perbedaan pendapat tentang hukum dasar perkawinan disebabkan perbedaan pandangan tentang orientasi makna kalimat perintah dalam ayat al-Qur`an dan hadis yang menjelaskan tentang perkawinan di atas, apakah menunjuk makna wajib, sunah ataukah mubah. Fuqaha yang berpendapat bahwa kawin itu wajib bagi sebagian orang, sunnah untuk sebagian orang yang lain, dan mubah untuk orang sebagian orang yang lain lagi, didasarkan atas pertimbangan kemaslahatan. Qiyas seperti inilah yang disebut qiyas mursal, kebanyakan ulama mengingkari qiyas tersebut, tetapi dalam mazhab Maliki tampak jelas hal itu dipegangi. ${ }^{38}$ Namun jelas dari penjelasan yang telah lalu, bahwa hukum dasar perkawinan dalam Islam adalah sunnah. Dalam sebuah hadis diriwayatkan ada sekelompok sahabat bertamu ke rumah Rasul bermaksud memperolah informasi perihal bâliyah ritual beliau ketika di rumah. Setelah diberitahu perihal ibadah Rasul sekolompok sahabat tersebut menganggap 'enteng' ibadah Rasul, dengan alibi bahwa Rasul

\footnotetext{
34 Wahbah Zuhailî, al-Fiqh al-Islâmî wa Adillatuh, (Damaskus: Dâr al-Fikr, 1985), 31-33.

35 'Abd al-Raḥmân al-Jazîrî, al-Fiqh 'alâ Madhâbib al-Arba'ah, (Dalam al-Maktab alShamilah), 8.

36 Al-Nawâwî, al-Majmû'..., 173.

${ }^{37}$ Al-Nawâwî, al-Majmû'..., 202.

38 Ibn Rushd, Bidayah....., 394.
} 
telah diampuni dosa-dosanya sehingga sangat wajar ibadahnya hanya dilakukan sekedarnya. Masing-masing kemudian menunjukkan tentang kelebihan ibadahnya masing-masing, ada yang selalu sholat malam, selalu berpuasa dan ada yang tidak akan menikah sama-sekali sampai akhir hayatnya. Mendengar pernyataan ini, Rasul kemudian datang menemuinya seraya berkata:

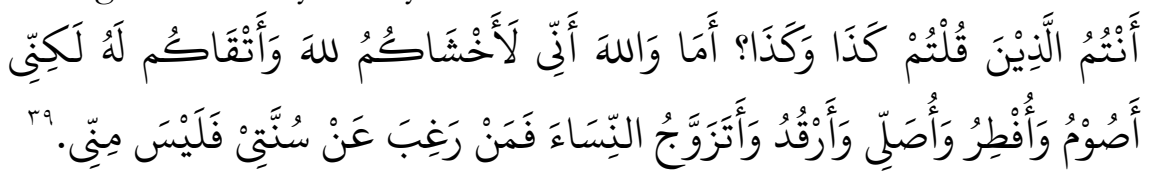

Artinya: "Engkau sekalian yang berkata demikian? Sunggung demi Allah saya adalah orang yang lebih takut dan lebih bertakwa kepada Allah diantara kalian semua, namun aku tetap berpuasa dan berbuka, sholat malam dan tidur, serta menikah dengan para perempuan. (Itulah sunabku), barang siapa benci sunabku maka dia termasuk golonganku."

e) Tujuan Perkawinan

Tentang tujuan perkawinan disebutkan dalam firman Allah dalam al-Qur'an surat an-Rum ayat 21 yang berbunyi:

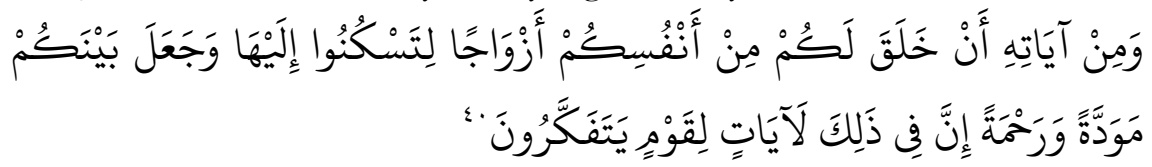

Artinya: "Dan diantara tanda-tanda kekuasaan-Nya ialah Dia menciptakan untukmu istri-istri dari jenismu sendiri, supaya kamu merasa cenderung dan merasa tentram kepada-Nya, dan dijadikan-Nya diantara kamu rasa kasih dan sayang. Sesunggubnya pada yang demikian itu benar-benar terdapat tanda-tanda bagi kaum yang berpikir." ${ }^{41}$

Berkaitan dengan ayat di atas, Sayyid Sâbiq mengatakan bahwa perkawinan adalah sunnah dari beberapa sunnah Allah dalam penciptaan mahluk-Nya. Perkawinan merupakan cara yang dipilih oleh Tuhan untuk hamba-Nya guna melakukan perkembangbiakan, memperbanyak spesies dan untuk meneruskan kehidupan yakni mendapatkan anak untuk masa depan yang akan datang. ${ }^{42}$

\footnotetext{
${ }^{39}$ Muhammad b. Ismâ'il al-Bukhârî, Al-Jâmi’ Sạ̧ịh, (Beirut: Dar Ibn Kathir, 1987), Vol. 5, 1949 .

40 Al-Qur'an, 30: 21.

${ }^{41}$ Departemen Agama RI, Al-Qur'an ....., 406.

42 Sayyid Sâbiq, Fiqh al-Sunnah, (Kairo: Dâr al-Sunnah, 2009), 7.
} 
f) Tatacara Pelaksanaan Perkawinan

Adapun tatacara dan runtututan pelaksanaan perkawinan menurut Islam adalah sebagai berikut:

1) Kbitbah (peminangan). Seorang muslim yang akan mengawini seorang muslimah hendaknya meminang terlebih dahulu, karena dimungkinkan ia sedang dipinang oleh orang lain, dalam hal ini Islam melarang seorang muslim meminang wanita yang sedang dipinang oleh orang lain. Dalam proses khitbah diperbolehkan pula untuk melihat wajah yang akan dipinang; Tentang peminangan ini berdasarkan pada:

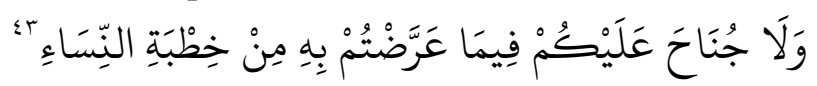

Artinya: "Tidak ada halangannya bagimu menggunakan kata sindiran dalam meminang perempuan." 44

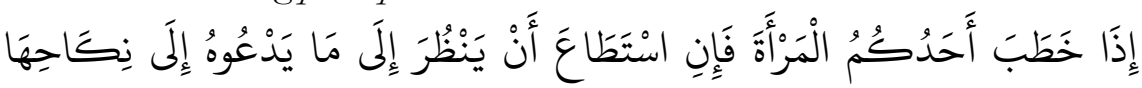
فَلْيَفْعَلْ

Artinya: "Bila salah seorang di antaramu meminang seorang perempuan, bila ia mampu melihatnya yang mendorongnya untuk mengawininya, maka lakukanlah."

2) Akad. Dalam akad perkawinan terdapat hal-hal yang harus terpenuhi, yakni syarat dan rukun perkawinan, diantaranya menyangkut kedua calon mempelai, Ijab-Qabul, Mahar, adanya Wali, adanya 2 orang saksi;

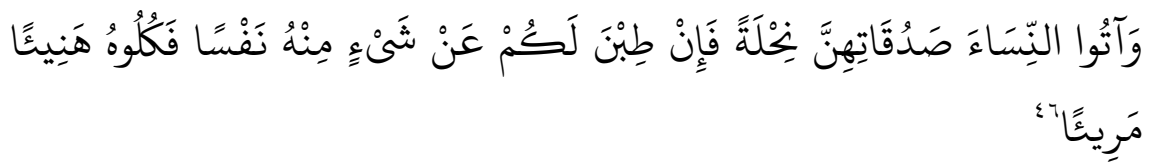

Artinya: "Berikanlah mahar kepada perempuan (yang kamu kawini) sebagai pemberian penub kerelaan. Kemudian jika mereka menyerabkan kepada kamu sebagian dari mahar itu dengan senang hati, maka makanlah pemberian itu (sebagai makanan) yang sedap lagi baike akibatnya." 47

\footnotetext{
43 Al-Qur'an, 2: 235.

44 Departemen Agama RI, Al-Qur'an ....., 38.

${ }^{45}$ Al-Sijistânî, Sunan Abî Dâwud....., 190.

46 Al-Qur'an, 4: 4.

${ }^{47}$ Departemen Agama RI, Al-Qur'an...., 77.
} 


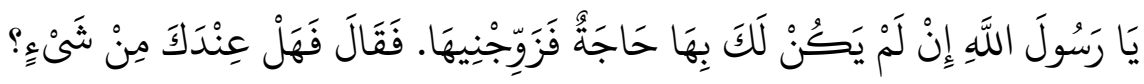

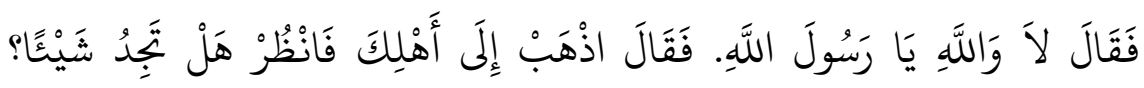

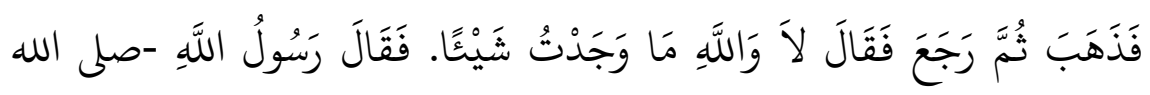

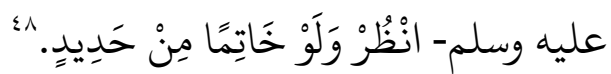

Artinya: "Ya Rasul Allab bila anda tidak punya keinginan untuke mengawininya, maka kawinkan saya dengannya. Nabi bersabda: apa kamu punya sesuatu?. Ia berkata: tidak ya Rasul Allah. Nabi bersabda: pergilab kepada keluargamu mungkin kamu akan mendapatkan sesuatu. Kemudian dia pergi dan segera kembali dan berkata: tidak, saya tidak memperoleh sesuatu ya Rasul Allah. Nabi bersabda: carilah walaupun hanya sebentuk cincin besi."

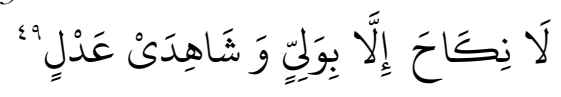

Artinya: "Tidak ada kawin tanpa wali dan kedua saksi yang adil."

3) Walimah. Walîmah al-'Urusy atau pesta perkawinan berhukum sunnah. Dalam pelaksanaannya diusahakan sesederhana mungkin dan mengundang orang-orang miskin. Dasar pelaksanaan walimah adalah hadis riwayat sahabat `Abd al-Rahman berbunyi:

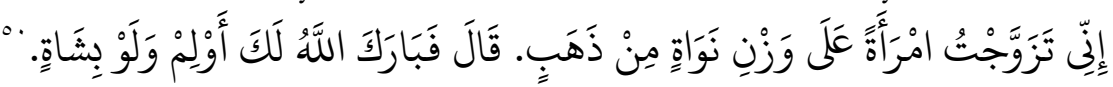

Artinya: "Saya baru saja mengawini seorang perempuan dengan maharnya lima dirbam. Nabi bersabda: Semoga Allab memberkatimu. Adakanlah perbelatan, walaupun hanya dengan memotong seekor kambing."

\footnotetext{
48 Abû al-Husain Muslim bin al-Hujjaj bin Muslim al-Qushairî al-Naisâbûrî, Sabịh Muslim, (Bairut: Dâr al-Afâq al-Jadîdah, t.th.), 143.

49 Muhammad Ḍiyâ' al-Raḥmân al-A'zamî, al-Sunan al-Sughrâ li al-Baihâqû, (Riyậ: Maktabah al-Rushd, 2001), 107.

${ }^{50}$ Al-Naisâbûrî, Sabịh Muslim...., 144.
} 


\title{
Perkawinan Dalam Agama Kristen
}

a) Pengertian Perkawinan

Pranata GKJW tentang Perkawinan BAB I Pengertian Dasar, Pasal: 1 menyebutkan:

\author{
"Perkawinan adalah pranata Tuban Allah yang berupa ikatan lahir \\ batin antara seorang pria dan seorang wanita sebagai suami-isteri, yang \\ dikehendaki dan ditentukan oleh kasib-Nya, dalam bentuk tata bidup \\ rumah tangga." 51
}

Adapun yang dimaksud dengan ungkapan "perkawinan dalam pranata Tuhan Allah" adalah bahwa Allah sendiri yang menata, memprakarsai, mengijinkan dan menuntun adanya perkawinan itu ${ }^{52}$. Meskipun demikian dalam hal pemilihan jodoh, warga yang bersangkutan berperan secara aktif, sebab perkawinan tersebut berupa ikatan lahir batin antara seorang pria dan wanita sebagai suami-isteri. GKJW mengakui bahwa perkawinan bukanlah sakramen (upacara suci

${ }^{51}$ Majelis Agung Gereja Kristen Jawi Wetan, Tata dan Pranata Greja Kristen Jawi Wetan dan Peraturan Majelis Agung Tentang Badan-badan Pembantu Majelis, (Malang: t.p., 1996), 171.

52 Majelis Agung Gereja Kristen Jawi Wetan, Lebih Dari Permata Katekaisasi Perkawinan (Malang: Majelis Agung Greja Kristen Jawi Wetan, t.th.), 14. Alkitab, Kejadian. 1: 28 dan 2: 18-24 dan Matius. 19: 4-6. Dalam Alkitab, Kej. 1: 28 disebutkan: ${ }^{28}$ Allah memberkati mereka, lalu Allah berfirman kepada mereka: "Beranakcuculah dan bertambah banyak; penubilah bumi dan taklukekanlah itu, berpuasalah atas ikan-ikan di laut dan burung-burung di udara dan atas segala binatang yang merayap di bumi.”. Dan Alkitab Kej. 2: 18-24 disebutkan: ${ }^{18}$ Tuhan Allab berfirman: "Tidak baik, kalau manusia itu seorang diri saja, Aku akan menjadikan penolong baginya, yang sepadan dengan dia." ${ }^{19}$ Lalu Tuhan Allab membentuk dari tanah segala binatang hutan dan segala burung di udara. Dibawa-Nyalah semuanya kepada manusia itu untuk melihat, bagaimana ia menamainya; dan seperti nama yang diberikan manusia itu kepada tiap-tiap makbluk yang bidup, demikianlah nanti nama makbluk itu. ${ }^{20}$ Manusia itu memberi nama kepada ternak, kepada burung-burung di udara dan kepada segala binatang butang, tetapi baginya sendiri ia tidak menjumpai penolong yang sepadan dengan dia. ${ }^{21}$ Lalu Tuban Allah membuat manusia itu tidak nyenyak; Ketika ia tidur, Tuban Allah mengambil salab satu rusuk dari padanya, lalu menutup tempat itu dengan daging. ${ }^{22}$ Dan dari rusuk yang diambil Tuban Allah dari manusia itu, dibangun-Nyalah seorang perempuan, lalu dibawah-Nyalab kepada manusia itu. ${ }^{23}$ Lalu berkatalah manusia itu: "Inilah dia, tulang dari tulangku dan daging dari dagingku. Ia dinamai perempuan, sebab ia diambil dari laki-laki." ${ }^{24}$ Sebab itu seorang laki-laki akan meninggalakn ayahnya dan ibunya dan bersatu dengan isterinya, sehingga keduanya menjadi satu daging. Serta Alkitab Mat. 19: 4-6 disebutkan: ${ }^{4}$ Jawab Yesus: "Tidaklah kamu baca, babwa Ia yang menciptakan manusia sejak semula menjadikan mereka laki-laki dan perempuan? ${ }^{5}$ Dan firman-Nya: sebab itu laki-laki akan meninggalkan ayah dan ibunya dan bersatu dengan isterinya, sehingga keduanya itu menjadi sau daging. "Demikianlah mereka bukan lagi dua, melainkan satu. Karena itu, apa yang telah dipersatukan Allah, tidak boleh diceraikan manusia". 
keagamaan), ${ }^{53}$ namun demikian kemuliaan dan kesucian perkawinan tetap perlu dijaga, baik sebelum maupun sesudah pengesahannya. ${ }^{54}$ Pranata ini berlaku untuk warga yang kawin, sedangkan warga yang tidak kawin (selibat) tidak melanggar pranata ini. ${ }^{55}$

b) Asas Perkawinan

Tentang asas perkawinan, dalam Alkitab Kejadian 2: 18-24 disebutkan:

"Tuban Allab berfirman: "Tidak baik, kalau manusia itu seorang diri saja, Aku akan menjadikan penolong baginya, yang sepadan dengan dia." Lalu Tuhan Allah membentuk dari tanah segala binatang butan dan segala burung di udara. Dibawa-Nyalah semuanya kepada manusia itu untuk melibat, bagaimana ia menamainya; dan seperti nama yang diberikan manusia itu kepada tiap-tiap makbluk yang bidup, demikianlah nanti nama makbluk itu. Manusia itu memberi nama kepada ternak, kepada burung-burung di udara dan kepada segala binatang butang, tetapi baginya sendiri ia tidak menjumpai penolong yang sepadan dengan dia. Lalu Tuhan Allah membuat manusia itu tidak nyenyak; ketika ia tidur, Tuban Allab mengambil salah satu rusuk dari padanya, lalu menutup tempat itu dengan daging. Dan dari rusuk yang diambil Tuhan Allah dari manusia itu, dibangun-Nyalah seorang perempuan, lalu dibawah-Nyalah kepada manusia itu. Lalu berkatalah manusia itu: "Inilah dia, tulang dari tulangku dan daging dari dagingku. Ia dinamai perempuan, sebab ia diambil dari laki-laki." Sebab itu seorang laki-laki akan meninggalakn ayahnya dan ibunya dan bersatu dengan isterinya, sehingga keduanya menjadi satu daging." "56

Lebih lanjut dalam Alkitab Matius 19: 4-6 juga disebutkan:

Jawab Yesus: "Tidaklah kamu baca, bahwa Ia yang menciptakan manusia sejak semula menjadikan mereka laki-laki dan perempuan? Dan firman-Nya: sebab itu laki-laki akan meninggalkan ayah dan ibunya dan bersatu dengan isterinya, sehingga keduanya itu menjadi sau daging. Demikianlah mereka bukan lagi dua, melainkan satu." 57

53 Pius A Partanto dan M Dahlan Al-Barry, Kamus Ilmiah Populer, (Surabaya: Arkola: 2001), 689.

54 Alkitab, Matius. 19: 4-6.

${ }^{55}$ Majelis Agung Gereja Kristen Jawi Wetan, Lebih Dari Permata...., 14.

${ }^{56}$ Alkitab, Kejadian 2: 18-24

${ }^{57}$ Alkitab, Matius 19: 4-6 
Kedua kandungan ayat di atas menggarisbawahi bahwa pada hakekatnya perkawinan adalah piranti penyatuan diantara dua orang; laki-laki dan perempuan. Kedua-duanya dianggap satu bukan dua sosok lagi. Sebab pada hakekatnya kedua orang itu pada mulanya juga satu orang. Oleh karenanya dalam agama Kristen asas perkawinan adalah monogami dan monoandri. Lebih lanjut dalam pranata GKJW tentang Perkawinan BAB I Pengertian Dasar, Pasal: 2 menyebutkan:

Dalam perkawinan itu, seorang pria tidak boleh beristeri lebih dari seorang wanita, dan seorang wanita tidak boleh bersuami lebih dari seorang pria. ${ }^{58}$

Penjelasan dari pasal di atas adalah bahwa GKJW hanya menerima dan membenarkan asas perkawinan monogami dan monoandri. ${ }^{59}$ Ini yang kemudian disebut sebagai sifat Hakiki Perkawinan yang khas dalam ajaran Kristen. Sifat hakiki itu ada dua hal, sebagai berikut :

1) Monogami yang didasarkan atas kesamaan mertabat pribadi yang sama antara pria dan wanita yang dianugerahkan cinta kasih yang total dan bersifat ekslusif atau dalam ajarannnya ikatan perkawinan hanya mungkin dilakukan dengan satu jodoh, sehingga terhalang dia mengadakan perkawinan dengan orang lain pada waktu yang sama;

2) Mempunyai sifat yang tidak terputuskan, sebab perkawinan yang termasuk dalam kategori Ratum et consummatum (antara dua orang yang sudah dibaptis dan sudah terjadi konsumasi dengan senggama suami isteri secara manusiawi) adalah bersifat mutlak tak dapat diputuskan, tanpa peduli apapun akibatnya. ${ }^{60}$

Dalam agama kristen perceraian dilarang, apapun alasannya. Sebab dalam Kristen perkawinan merupakan prakarsa Tuhan untuk menyatukan kedua orang. Apa yang sudah disatukan oleh Tuhan tidak boleh lagi manusia memisahkannya. Bahkan jika seorang bercerai dia tidak boleh kawin lagi, dan jika kemudian kawin lagi, maka hal itu dianggap sebagaimana perzinahan. Hal ini berdasarkan Alkitab Matius 19: 4-6 berbunyi:

\footnotetext{
${ }^{58}$ Majelis Agung Gereja Kristen Jawi Wetan, Tata dan Pranata Greja Kristen Jawi Wetan, 171.

${ }_{59}$ Majelis Agung Gereja Kristen Jawi Wetan, Lebih Dari Permata..., 14.

${ }^{60}$ Ra'uf Ibnu Mu'thi, "Perkawinan menurut agama kristen katolik dan protestan" dalam http://roufibnumuthi.blogspot.com/2011/05/perkawinan-menurut-agamakristen.html?m=1 diakses Kamis 05 Mei 2011.
} 
Jawab Yesus: "Tidaklah kamu baca, bahwa Ia yang menciptakan manusia sejak semula menjadikan mereka laki-laki dan perempuan? Dan firman-Nya: sebab itu laki-laki akan meninggalkan ayah dan ibunya dan bersatu dengan isterinya, sehingga keduanya itu menjadi sau daging. Demikianlab mereka bukan lagi dua, melainkan satu. Karena itu, apa yang telah dipersatukan Allah, tidak boleb diceraikan manusia".

Tentang tidak bolehnya kawin lagi setelah bercerai dalam 1 Korintus 7: 10-11 dinyatakan:

Kepada orang-orang yang telah kawin aku - tidak, bukan aku, tapi Tuban - perintabkan, supaya seorang isteri menceraikan suaminya. Dan jikalau ia bercerai, ia harus tetap bidup tanpa suami atan isteri atan berdamai dengan suaminya. Dan seorang suami tidak boleh menceraikan isterinya. $^{62}$

Sedangkan tentang status perzinaan bagi sumai atau istri yang menikah lagi setelah perceraian disebutkan dalam Matius 19: 10-12:

Ketika mereka sudah di rumah, murid-murid itu bertanya pula kepada Yesus tentang hal itu. Lalu kata-Nya kepada mereka: "Barangsiapa menceraikan isterinya lalu kawin dengan perempuan lain, ia bidup dalam perzinahan terhadap isterinya itu. Dan jika si isteri menceraikan suaminya dan kawin dengan laki-laki lain, ia berbuat zinah.

c) Rukun dan Syarat Sah Perkawinan

Agama Kristen memperbolehkan perkawinan beda agama, bahwasanya seorang laki-laki Kristen yang menikahi wanita yang tidak beragama Kristen, maka wanita tersebut akan dikudus oleh laki-laki tersebut. Begitu juga sebaliknya. Hal ini sebagaimana yang terdapat dalam Korintus 1: 13-14, berbunyi.

Dan kalau ada seorang isteri bersuamikan seorang yang tidak beriman dan laki-laki itu mau bidup bersama-sama dengan dia, janganlah ia menceraikan laki-laki itu. Karena suami yang tidak beriman itu dikuduskan oleb isterinya dan isteri yang tidak beriman itu dikuduskan oleh suaminya. Andaikata tidak demikian, niscaya anak-anakmuadalab anak cemar, tetapi sekarang mereka adalab anak-anak kudus. ${ }^{64}$

\footnotetext{
${ }^{61}$ Alkitab, Matius 19: 4-6.

${ }^{62}$ Alkitab, Korintus 7: 10-11.

${ }^{63}$ Alkitab, Matius 19: 10-12.

${ }^{64}$ Korintus 1: 13-14.
} 
Untuk menetapkan hukum perkawinan sah dan tidaknya, maka didasarkan pada rukun dan syaratnya. Rukun perkawinan menurut agama Kristen adalah:

1) Calon suami;

2) Calon isteri;

3) Kedua orang saksi;

4) Ucapan untuk menjalin hidup bersama.

Dan Syarat-Syarat perkawinan terdapat pada Pranata GKJW tentang Perkawinan Bab II, Pasal: 4, 5, 6, 7, 8, 9, 10, dan 11 yang berbunyi:

Syarat-syarat perkawinan:

Pasal 4

Calon suami dan calon isteri pada waktu pelaksanaan perkawinan harus sudah cukup umur menurut ketentuan yang berlaku dan harus sudah mengaku percaya.

Pasal 5

Calon suami dan calon isteri harus mengajukan sendiri permohonan perkawinan mereka kepada Majelis Jemaat dimana perkawinan akan dilangsungkan.

Pasal 6

Permohonan perkawinan didasarkan atas kehendak calon kedua mempelai, sesuai dengan pengakubannya.

Pasal 7

Permobonan perkawinan diajukan sekurang-kurangnya 90 hari sebelum tanggal pelaksanaan perkawinan; dan sekurang-kurangnya 21 hari sebelum tanggal pelaksanaannya itu diajukan ulang dengan disertai kelengkapan perkawinan dan diikutkan oleh kedua orang saksi.

Pasal 8

Kalau salah seorang atau kedua calon mempunyai cacad dan/ atau penyakit yang jelas berbahaya bagi kebidupan berumah-tangga (berkeluarga), Majelis Jemaat harus memberikan pertimbangan khusus. Pasal 9

Yang tidak boleh kawin ialah:

Orang tuan dengan anaknya; kakek/nenek dengan cucu atau keturunanketurunannya, meskipun anak dari perkawinan yang sah atau tidak.

Saudara sekandung laki-laki dan perempuan, atau yang satu bapak lain ibu; demikian juga sebaliknya.

Bibi dengan kepenakan laki-laki, nenek dengan cucu kemenakan lakilaki.

Pasal 10 
Kalau calon suami dan isteri masib terikat sebagai saudara sepupu, maka permohona mereka harus mendapat pertimbangan khusus dari Majelis Jemaat dan PHMD.

Pasal 11

Kalau calon suami atau isteri bukan jemaat GKJW atau bukan dari satu Jemaat GKJW, diperlukan surat pengantar penyerahan pelayanan perkawinan dari Majelis Jemaat asal calon tersebut.65

Di Negara Indonesia perkawinan diatur dalam bentuk undangundang dan peraturan pelaksanaan. ${ }^{66}$ Fungsi gereja menurut undangundang adalah mengesahkan dan memberkati sebuah pelaksanaan perkawinan. Sebab dalam Undang-undang itu terdapat pernyataan "Perkawinan adalah sah, apabila dilakukan menurut hukum masingmasing agamanya dan kepercayaannya itu". ${ }^{67}$ Sementara itu dalam hal ini fungsi Negara menurut undang-undang adalah catatan sipil, maksudnya mencatat perkawinan yang telah disahkan oleh gereja. ${ }^{68}$ Dari sini akhirnya pengantin mendapatkan dua surat perkawinan sekaligus, yaitu surat perkawinan grejawi dan surat perkawinan dari Negara dalam hal ini dari catatan sipil. Dalam pelaksanaannya surat perkawinan dari catatan sipil lebih memiliki arti penting bagi pengantin, khususnya yang berkaitan dengan urusan-urusan formal kemasyarakatan. Gereja bersifat mendampingi agar permasalahan itu dapat diselesaikan dengan baik tanpa adanya perceraian. Yang berhak memutuskan perceraian adalah pengadilan. ${ }^{69}$

d) Hukum Perkawinan

Hukum perkawinan dalam agama kristen diutarakan dalam 1 Korintus 7 ayat 1 dan 2 berbunyi:

Dan sekarang tentang hal-hal yang kamu tuliskan kepadaku. Adalah baik bagi laki-laki, kalan ia tidak kawin, tetapi mengingat bahaya pencabulan, baiklah setiap laki-laki mempunyai isterinya sendiri dan setiap perempuan mempunyai suaminya sendiri.

Lebih lanjut dalam 1 Korintus 7 ayat 6 - 9 disebutkan:

\footnotetext{
65 Majelis Agung Gereja Kristen Jawi Wetan, Tata dan Pranata Greja Kristen Jawi Wetan, 172-173.

${ }^{66}$ Majelis Agung Gereja Kristen Jawi Wetan, Lebih Dari Permata..., 26-28.

${ }^{67}$ UU No. 1 Tahun 1974 tentang Perkawinan, Pasal: 2, Ayat 1.

${ }^{68}$ UU No. 1 Tahun 1974 tentang Perkawinan, Pasal: 2, Ayat 2.

${ }^{69}$ Majelis Agung Gereja Kristen Jawi Wetan, Lebib Dari Permata...., 26-28.

701 Korintus 7 ayat 1 dan 2.
} 
Hal ini kukatakan kepadamu sebagai kelonggaran, bukan sebagai perintah. Namun demikian alangkah baiknya, kalau semua orang seperti aku; tetapi setiap orang menerima Allah karunianya yang khas, yang seorang karunia ini, yang lain karunia itu. Tetapi kepada orang-orang yang tidak kawin dan kepada janda-janda aku anjurkan, supaya baiklah mereka tinggal dalam keadaan seperti aku. Tetapi kalau mereka tidak menguasai diri, baiklah mereka kawin. Sebab lebih baik kawin dari pada hangus karena hawa nafsu. ${ }^{71}$

Ayat di atas merupakan salah satu isi surat Rasul Paulus kepada masyarakat Korintus. Dari sini diketahui bahwa dalam agama Kristen lebih baik seseorang tidak menikah demi untuk pengabdiannya kepada Tuhan. Namun, mengingat maraknya percabulan maka hukum perkawinan berubah menjadi lebih baik menikah. Hukum dasar lebih baik tidak menikah ini deperkuat oleh kenyataan bahwa Tuhan Yesus dan Rasul Paulus yang tidak menikah sampai akhir hayatnya.

e) Tujuan Perkawinan

Pranata GKJW tentang Perkawinan BAB I, Pasal: 3 menyebutkan:

Tujuan perkawinan adalab kehidupan rumah tangga yang bahagia, lestari dan ikut serta dalam karya Tuban Allah. ${ }^{72}$

Maksudnya adalah persekutuan keluarga Kristen adalah bagian dari persekutuan jemaat yang bersangkutan. Jemaat yang bersangkutan adalah bagian dari GKJW dan GKJW adalah anggota tubuh kristus. Oleh karena itu kebahagiaan suami isteri atau keluarga Kristen tidak dapat dipisahkan dari kegiatan jemaat dan pelaksanaan Kepercayaan dan panggilan GKJW serta rencana karya Tuhan Allah pada umumnya. Kata "lestari" menyatakan bahwa ikatan suami isteri itu berlaku sepanjang hidup dan oleh karena itu GKJW tidak mengatur tentang perceraian. ${ }^{73}$

Seorang isteri terikat oleh hukum kepada suaminya selama suaminya itu hidup. Akan tetapi apabila suaminya itu mati, bebaslah ia dari hukum yang mengikatnya kepada suaminya itu. ${ }^{74}$

\footnotetext{
711 Korintus, 7 ayat 6-9.

${ }^{72}$ Majelis Agung Gereja Kristen Jawi Wetan, Tata dan Pranata Greja Kristen Jawi Wetan, 171.

${ }_{73}$ Majelis Agung Gereja Kristen Jawi Wetan, Lebih Dari Permata..., 14.

${ }^{74}$ Roma, 7: 2. ${ }^{2}$ Sebab seorang isteri terikat oleh bukum kepada suaminya selama suaminya itu bidup. Akan tetapi apabila suaminya itu mati, bebaslah ia dari bukum yang mengikatnya kepada suaminya itu. (Rom, 7: 2)
} 
Setiap orang Kristen yang sudah berumah tangga terikat kepada hukum perkawinan yang telah dibuat dan ditetapkan oleh Tuhan. Hukum perkawinan yang ada di dalam rumah tangga Kristen diatur oleh kebenaran firman Tuhan dan bukan diatur oleh hukum duniawi yang dibuat oleh manusia. Itu sebabnya, setiap rumah tangga harus tunduk dan taat kepada Yesus Kristus yang adalah kepala rumah tangga. ${ }^{75}$

Namun, sekarang banyak rumah tangga Kristen tidak lagi tunduk kepada hukum perkawinan dengan melakukan perceraian, poligami, poliandri, perzinahan, istri tidak tunduk kepada suami, suami tidak mengasihi istri dan lain sebagainya. Rumah tangga sudah berjalan sesuai dengan keinginan sendiri dan mengabaikan perintah Tuhan untuk tetap setia sampai maut menjemput.

Apabila sedang mengalami masalah rumah tangga dan tengah berada diambang kehancuran, maka bahwa Tuhan Yesus membenci perceraian. ${ }^{76}$ Perceraian bukanlah pilihan. Perceraian akan membawa kepada kehancuran yang lebih parah karena Iblis akan merasa senang akan hal ini. Tentang larangan perceraian ini disebutkan dalam alKitab:

Dan jikalau ia bercerai, ia harus tetap hidup tanpa suami atau isteri atau berdamai dengan suaminya. Dan seorang suami tidak boleh menceraikan isterinya.

f) Tatacara Pelaksanaan Perkawinan

Pranata GKJW tentang Perkawinan BAB III, Pasal: 12, 13, dan 14 menyebutkan:

Pasal 12:

Perkawinan dilaksanakan dan disabkan di depan Jemaat dalam ibadah perkawinan yang dilakukan ditempat Jemaat melaksanakan ibadah dengan memakai ibadah yang ditetapkan.

Pasal 13 a

\footnotetext{
${ }^{75}$ Efesus, 5: 22-24. ${ }^{22}$ Hai isteri, tunduklah kepada suamimu seperti kepada Tuhan, ${ }^{23}$ karena suami adalah kepala isteri sama seperti Kristus adalah kepala jemaat. Dialah yang menyelamatkean tubuh. ${ }^{24}$ Karena itu sebagai jemaat tunduk kepada Kristus, demikian jugalah isteri kepada suamidalam segala sesuatu. (Ef, 5: 22-24)

${ }^{76}$ Maleakhi, 2: 16. ${ }^{16}$ Sebab aku membenci perceraian, firman Tuban, Allab Israel -juga orang yang menutupi pakaiannya dengan kekerasan, firman Tuhan semesta alam. Maka jagalab dirimu dn janganlah berkhianat! (Mal, 2: 16)

771 Korintus 7 ayat 11.
} 
Penanggungjawab pelaksanaan perkawinan adalah Majelis Jemaat yang bersangkutan dan pelayanan ibadahnya adalah Pendeta Greja Kristen Jawi Wetan yang melayani Jemaat yang bersangkutan.

Pasal 13 a

Bila pendeta yang melayani Jemaat yang bersangkutan berhalangan, maka Majelis Jemaat dapat meminta pendeta untuk melayani Ibadah Perkawinan tersebut.

Pasal 14

Waktu pelaksanaan perkawinan ditentukan oleh Majelis Jemaat yang bersangkutan, setelah bersama-sama yang bersangkutan mengadakan pertimbangan dengan penub kebijaksanaan. ${ }^{78}$

\section{Analisis Komparatif}

1) Pengertian Perkawinan

Pengertian perkawinan menurut Islam adalah:

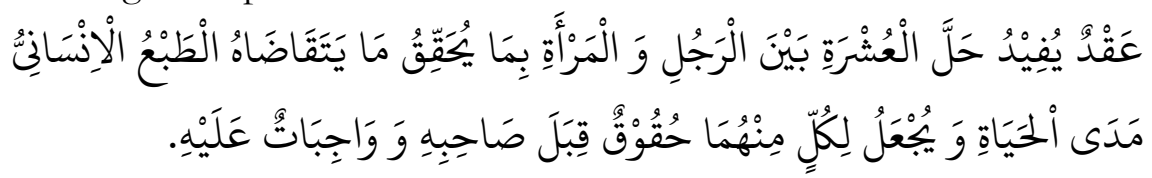

Artinya: "Akad yang menimbulkan kebolehan bergaul antara laki-laki dan perempuan dalam tuntutan naluri kemanusiaan dalam kebidupan, dan menjadikan untuk. kedua belah pihak secara timbal balik. hakbake dan kewajiban-kewajiban.

Sedangkan pengertian perkawinan menurut Kristen adalah:

Perkawinan adalah pranata Tuban Allah yang berupa ikatan labir batin antara seorang pria dan seorang wanita sebagai suami-isteri, yang dikehendaki dan ditentukan oleh kasib-Nya, dalam bentuk tata bidup rumah tangga.

Dari dua pengertian di atas terdapat persamaan yang mendasar yakni setelah adanya akad perkawinan maka timbulah sebuah ikatan dan hubungan lahir batin antara seorang perempuan dan laki-laki yang sebelumnya hubungan tersebut diharamkan oleh agama, baik agama Islam maupun Kristen, hubungan tersebut akan menimbulkan hakhak dan kewajiban antara keduanya sesuai dengan tuntunan Tuhan. Artinya, menurut Islam dan Kristen perkawinan merupakan tuntunan dan ajaran agama yang bernilai ibadah.

${ }_{78}$ Majelis Agung Gereja Kristen Jawi Wetan, Tata dan Pranata Greja Kristen Jawi Wetan, 173-174. 
Sedangkan perbedaan dari keduanya adalah, perkawinan menurut Islam adalah akad sedangkan menurut Kristen adalah pranata Tuhan Allah. Kata "akad", menimbulkan pengertian bahwa perkawinan tersebut yang aktif melakukannya adalah antara kedua mempelai lakilaki dan perempuan, meskipun sebenarnya Tuhanlah yang menjalankan. Kata "pranata Tuhan Allah" mempunyai pengertian bahwa Allah sendiri yang menata, memprakarsai, mengijinkan dan menuntun adanya perkawinan itu. Meskipun dalam pemilihan jodoh, kedua mempelai yang bersangkutan berperan secara aktif. Sehingga dapat disimpulkan jika dalam Islam perkawinan menyangkut dimensi horisontal dan vertikal sedangkan dalam Kristen lebih dominan dimensi vertikalnya.

2) Asas Perkawinan

Agama Islam menetapkan 6 (enam) asas perkawinan, yaitu: (a) Membentuk keluarga yang bahagia dan kekal; (b) Dilakukan menurut hukum Islam; (c) Monoandri tertutup dan monogami terbuka; (d) Masak jiwa raganya untuk melangsungkan perkawinan; (e) Mempersulit percaraian; (f) Hak dan kedudukan suami istri adalah seimbang. Sedangkan Hukum agama Kristen menetapkan asas perkawinan secara global menjadi 2 (dua) asas, yaitu: (a) Monoandri dan Monogami tertutup yang didasarkan atas kesamaan mertabat pribadi yang sama antara pria dan wanita yang dianugerahkan cinta kasih yang total dan bersifat ekslusif atau dalam ajarannnya ikatan perkawinan hanya mungkin dilakukan dengan satu jodoh, sehingga terhalang dia mengadakan perkawinan dengan orang lain pada waktu yang sama; (b) Mempunyai sifat yang tidak terputuskan, sebab perkawinan yang termasuk dalam kategori Ratum et consummatum (antara dua orang yang sudah dibaptis dan sudah terjadi konsumasi dengan senggama suami isteri secara manusiawi) adalah bersifat mutlak tak dapat diputuskan, tanpa peduli apapun akibatnya.

Dari uraian di atas, terdapat $\mathrm{du}$ asa saja yang dapat diperbandingkan, yakni menyangkut asas monoandri dan monogami serta tentang perceraian atau kelanggengan perkawinan. Islam dan Kristen sama-sama menganut asas monoandri dan monogami. Bedanya hanya jika dalam Islam menganut asas monogami terbuka, artinya seseorang diperbolehkan beristri lebih dari satu jika memang memenuhi persyaratan dapat berbuat adil diantara para istrinya. Sedangkan dalam Kristen adalah monogami tertutup. Karena dalam ajaran Kristen, sebuah ikatan perkawinan hanya mungkin dilakukan 
dengan satu jodoh, sehingga terhalang dia mengadakan perkawinan dengan orang lain pada waktu yang sama.

Sedangakan menyangkut kelanggengan dalam perkawinan, untuk membentuk keluarga yang bahagia dan kekal, maka Islam memasukkan asas mempersulit perceraian, dan juga menurut Islam perceraian adalah sebuah tindakan yang diperbolehkan Tuhan dengan syarat Tuhan sangat membencinya. Hal ini sangat berbeda dengan agama Kristen, Kristen tidak memperbolehkan adanya perceraian, tidak lagi mempersulit, dikarenakan perkawinan termasuk dalam kategori Ratum et consummatum (antara dua orang yang sudah dibaptis dan sudah terjadi konsumasi dengan senggama suami isteri secara manusiawi) adalah bersifat mutlak tak dapat diputuskan, tanpa peduli apapun akibatnya. Menurut Kristen orang yang telah melakukan perkawinan adalah satu, bukan lagi dua. Karena itu, apa yang telah dipersatukan Allah, tidak boleh diceraikan manusia. Seorang yang telah bercerai tidak boleh melakukan perkawinan lagi, dan jika melakukan perkawinan maka hal ini termasuk perbuatan zina.

3) Rukun dan Syarat Sah Perkawinan

Kedua agama, yaitu Islam dan Kristen memberikan sebuah aturan, bahwasanya perkawinan dianggap sah jika sesuai dengan agama yang dianut, dan untuk mendapatkan perkawinan yang sah maka kedua agama mempunyai tolak ukur, yaitu menurut Islam dalam perkawinan haruslah terdapat 5 (lima) hal dan menurut Kristen 4 (empat), jika tidak maka perkawinannya dianggap batal. 5 (lima) hal menurut Islam adalah calon suami, calon isteri, wali kawin, dua orang saksi dan ijab dan kabul. Dan 4 (empat) hal menurut Kristen adalah Calon suami, calon isteri, kedua orang saksi dan ucapan untuk menjalin hidup bersama. Segi perbedaanya terdapat dalam hal wali perkawinan, dalam Islam mengharuskan adanya wali perkawinan, dikarenakan sebenarnya yang memiliki hak atas wanita yang menikah adalah orang tuanya, bukan dirinya. Dalam Kristen tidak demikian adanya, mereka tidak mengharuskan adanya wali dalam perkawinan dikarenakan yang melakukan perkawinan adalah kedua mempelai bukanlah orang tua mereka.

Sedangkan menyangkut perkawinan campuran terdapat perbedaan yang cukup mencolok. Jika dalam Islam perkawinan campuran tidak boleh, hanya kecuali bagi lelaki muslim yang menikahi perempuan kitâbiyah. Sedangakan dalam Kristen hal ini diperbolehkan dengan tanpa memberi catatan sedikitpun. Sebab dalam ajaran Kristen jika 
salah satu pasangan berlainan agamanya maka akan terkuduskan oleh salah satu pasangan yang lain.

4) Hukum Perkawinan

Jika dalam Islam, hukum asal perkawinan adalah Sunnah, maka tidak demikian halnya dengan Kristen, yang menyatakan lebih baik tidak menikah jika tidak dikhawatirkan berbuat percabulan. Dan jika dikhawatirkan maka lebih baik menikah.

Persamaan diantara Islam dan Kristen tentang hukum perkawinan terletak pada adanya perubahan hukum asal jika memang terdapat faktor lain yang mendorongnya, semisal takut terjadi perzinaan dan atau takut membuat kedzaliman terhadap seorang istri.

Baik dalam Islam maupun dalam Kristen fluktuasi hukum perkawinan tidak didasarkan pada status sosial keagamaan tertentu, misalnya ulama dan pendeta, namun didasarkan atas pertimbangan keselamatan dalam menjalankan agama, semisal apakah ditakutkan berbuat zina.

Ketentuan ini tentunya berbeda dengan apa yang ada dalam aturan perkawinan Katolik. Dikalangan umat Katolik terdapat aturan tentang penghalang perkawinan, baik yang menyangkut halangan nikah muabbad maupun halangan nikah Grejawi. Salah satu halangan nikah Grejawi adalah halangan nikah sebab tahbisan suci. Dalam aturan yang tertuang dalam kanon 1087 disebutkan bahwa seorang yang telah melakukan tahbisan suci dilarang untuk menikah. Sehingga para uskup, imam, diakon dan lain sebagainya terlarang untuk melakukan perkawinan agar mereka semata-mata menjadi pelayan-pelayan Gereja.

5) Tujuan Perkawinan

Dalam Islam, perkawinan mempunyai tiga tujuan, yaitu: Sakinah (ketentraman), Mawaddah (kasih sayah), dan Rahmah (saling mengasihi). Sedangkan dalam Kristen perkawinan juga mempunyai tiga tujuan, yaitu bahagia, Lestari, dan Ikut serta dalam karya Tuhan Allah. Tidak terdapat perbedaan yang prinsipil antara tujuan perkawinan dalam Islam dan Kristen.

Perbedaan hanya terletak dalam hal "ikut serta dalam karya Tuhan Allah", dikarenakan perkawinan masuk dalam pranata Tuhan Allah, maksudnya bahwa Allah sendiri yang menata, memprakarsai, mengijinkan dan menuntun adanya perkawinan itu. Tidak demikian halnya dalam Islam, sebab dalam Islam yang mengadakan hubungan perkawinan adalah manusia itu sendiri. 
6) Tatacara Pelaksanaan Perkawinan

Dalam hal tatacara melaksanakan perkawinan terdapat persamaan dan perbedaan diantara agama Islam dan Kristen. Persamaannya terletak pada adanya akad perkawinan, bedanya kalau dalam Islam akad dilkasanakan oleh calon suami dengan wali calon istrinya, sedangkan dalam Kristen akad dilakukan antara calon suami dan calon istri.

\section{Kesimpulan}

Ketentuan pranata perkawinan dalam agama Islam dan Kristen diatur berlandaskan isi dan ajaran kitab suci masing-masing yang selanjutnya diatur lebih detail dalam kitab-kitab turunannya, sepanjang menyangkut asas, hukum, tujuan, syarat, dan rukun perkawinan serta yang berkaitan dengan putusnya ikatan perkawinan. Secara umum, perkawinan menurut Islam adalah sebuah akad yang menimbulkan kebolehan bergaul antara laki-laki dan perempuan dan adanya hak dan kewajiban yang berlandaskan motif keagamaan. Sedangkan perkawinan menurut Kristen adalah pranata Tuhan Allah yang berupa ikatan lahir batin antara seorang pria dan seorang wanita sebagai suami-isteri, yang dikehendaki dan ditentukan oleh kasih-Nya, dalam bentuk tata hidup rumah tangga. Dengan demikian, perkawinan dalam Islam dapat dikatakan mempunyai dimensi ganda; dimensi vertikal dan horisontal, sedangkan dalam Kristen lebih dominan dimensi vertikal meskipun juga terdapat dimensi horisontal.

Pada dasarnya terdapat beberapa persamaan dan perbedaan mengenai pranata perkawinan dalam agama Islam dan Kristen yang cukup banyak. Namun diantara beberapa hal yang begitu mencolok terlihat pada masalah hukum asal perkawinan, poligami, kelanggengan perkawinan dan masalah kawin campur.

Kajian tentang hukum perkawinan agama-agama patut mendapat perhatian oleh para akademisi yang bergelut dalam hukum keluarga. Apa yang tertulis dalam makalah ini hanya semacam pengantar memasuki halhal yang lebih spesifik dan dalam. Oleh karenanya sangat diperlukan kajian lebih lanjut. 


\section{Daftar Pustaka}

Al-Kitab.

Al-Qur'an.

A'ẓamî (al), Muḥammad Dịîâ' al-Raḥmân. Al-Sunan al-Sughrâ li al-Bayhaqî. Riyâd: Maktabah al-Rushd, 2001.

Pius A Partanto dan M. Dahlan al-Barry. Kamus Ilmiah Populer. Surabaya: Arkola, 2001.

Bukhârî̀ (al), Muḥammad b. Ismâ'il. Al-Jâmi’ al-Șaḅih, Beirut: Dâr Ibn Kathîr, 1987. Vol. V.

Departemen Agama RI. Al-Qur'an dan Terjemahannya. Bandung: Menara Kudus, 2006.

Jazîrî (al), 'Abd al-Raḥmân. Al-Fiqh 'alâ Madhâbib al-Arba'ah. Kairo: Dâr al-Hadîth, 2004.

Majelis Agung Gereja Kristen Jawi Wetan. Lebih Dari Permata. Malang: 2000 . . Tata dan Pranata Greja Kristen

Jawi Wetan dan Peraturan Majelis Agung Tentang Badan-badan Pembantu Majelis. Malang: t.p., 1996.

Mu'thi, Ro'uf Ibnu. "Perkawinan menurut agama kristen katolik dan protestan" dalam http://roufibnumuthi.blogspot.com/2011/ 05/perkawinan-menurut-agama-kristen.html?m=1 diakses Kamis 05 Mei 2011.

Muhammad, Abdul Kadir. Hukum Perdata Indonesia. Bandung: PT. Citra Aditya Bakti, 2000.

Naisâbûrî (al), Abû al-Ḥusain Muslim bin al-Hujujaj bin Muslim alQushairî. Șahịh Muslim. Bairut: Dâr al-Afâq al-Jadîdah, t.th.

Nawawî (al), 'Abû Zakariyyâ Muhyî al-Dîn Yahya bin Sharf. al-Majmû' Sharb Mubadhdhab. Jeddah: al-Maktab al-Irshâd, t.th.

Usaha Keluarga, t.th. - Al-Tafsîr al-Munîr li Ma'âlim al-Tañîl. Semarang:

Qazwinî (al), Muḥammad bin Yazîd Abû 'Abdullâh. Sunan Ibn Mâjah. Bairut: Dâr al-Fikr, t.th.

Rafiq, Ahmad. Hukum Islam di Indonesia. Jakarta: PT. Raja Grafindo Persada, 2003.

Rushd, al-Faqîh Abû al-Wâhị Muhammad bin Aḥmad bin Muhammmad bin. Bidâyat al-Mujtabid. Jakarta: Pustaka Amani, 2007.

Sâbiq, Sayyid. Fiqh al-Sunnah. Kairo: Dâr al-Sunnah, 2009. 
Sijistânî (al), Abû Dâwud Sulaimân bin al-Ash'ab. Sunan Ab̂̀ Dâwud. Bairut: Dâr al-Kitâb al-'Arâbî, t.th.

Sîwâsî (al), Kamâl al-Dîn Muhammad bin 'Abd al-Wahîid. Sharh Fatḥ alQadîr. Bairut: Dâr al-Fikr, t.th.

Soemiyati. Hukum Perkawinan Islam dan Undang-Undang Perkawinan. Yogyakarta: Liberty, 1999.

Syarifuddin, Amir. Hukum Perkawinan Islam di Indonesia. Jakarta: Prenada Media, 2007.

Anșânî (al), Zakariyâ bin Muḥammad bin Aḥmad bin Zakariyâ. Fath alWahâb bi Sharb Manhâj al-Tullâb. Bairut: Dâr al-Kutub al'Ilmiyah, $1418 \mathrm{H}$.

Zuhailî (al), Wahbah. al-Fiqh al-Islâmî wa Adillatuh. Damaskus: Dâr alFikr, 1985. 